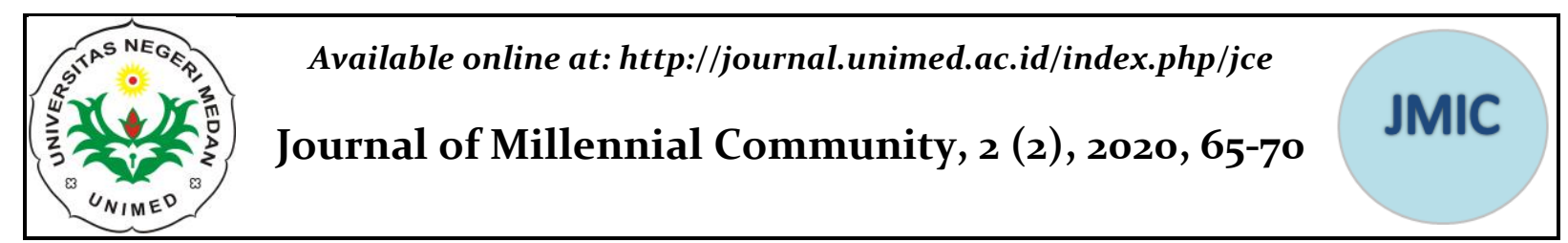

\title{
Hubungan Perhatian Orangtua Dengan Hasil Belajar Anak Usia 10 - 12 Tahun Di Desa Kuta Pengkih Kecamatan Marding-Ding
}

\author{
Sani Susanti ${ }^{1}$, Feby Narco Kacaribu ${ }^{2}$ \\ Prodi Pendidikan Masyarakat, Universitas Negeri Medan \\ Email: susanti.sani@gmail.com
}

\begin{abstract}
Abstrak
Tujuan dari penelitian ini adalah untuk mengetahui hubungan perhatian orangtua dengan hasil belajar anak usia 10-12 tahun di Desa Kuta Pengkih Kecamatan Marding-ding. Jenis penelitian mengunakan penelitian kuantitatif dengan pendekatan deskriptif. Populasi penelitian adalah orangtua yng memiliki anak usia 10-12 tahun yang ada di Desa Kuta Pengkih Kecamatan Marding-ding yaitu berjumlah 271 orang tua, teknik pengambilan sampel dalam penelitian ini adalah proporsional random sampling yaitu orangtua sebanyak 41 orang tua yang memilii anak usia 10-12 tahun dan tinggal di Desa Kuta Pengkih Kecamtan Marding-ding. Alat yang digunakan pada teknik pengumpulan data adalah angket dan dokumentasi. Teknik analisi yang digunakan adalah korelasi product moment dan uji-t. Berdasarkan pengolahan data dengan rumus korelasi product moment diperoleh hasi perhitungan rhitung sebesar o,548 sedangkan rtabel sebesar 0,308. Maka rhitung $>$ rtabel, sehingga terdapat korelasi antara veriabel $\mathrm{X}$ dan variable $\mathrm{Y}$ memiliki hubungan yang positif.
\end{abstract}

Kata Kunci: Perhatian Orang Tua, Hasil Belajar Anak

\section{The Relationship between Parents' Attention and Learning Outcomes of Children aged 10-12 Years in Kuta Pengkih Village, Marding-Ding District}

\begin{abstract}
The purpose of this study was to determine the relationship between parental attention and learning outcomes of children aged 10-12 years in Kuta Pengkih Village, Mardingding District. This type of research uses quantitative research with a descriptive approach. The study population was parents who had children aged 10-12 years in Kuta Pengkih Village, Marding-ding District, totaling 271 parents, the sampling technique in this study was proportional random sampling, namely 41 parents who had children aged 10- 12 years and lives in the village of Kuta Pengkih, Kecamtan Marding-ding. The tools used in data collection techniques are questionnaires and documentation. The analysis technique used is the product moment correlation and t-test. Based on data processing with the product moment correlation formula, the calculation result of $r$ count is 0.548 while $r$ table is 0.308 . Then rcount> rtable, so that there is a correlation between the $\mathrm{X}$ variable and the $\mathrm{Y}$ variable, which has a positive relationship.
\end{abstract}

Keywords: Leadership, Meaning of Change and Organizational Performance 


\section{PENDAHULUAN}

Pada era globalisasi seperti ini perkembangan ilmu pengetahuan dan teknologi sangat pesat, khususnya di dalam bidang pendidikan. Pendidikan merupakan suatu kebutuhan yang harus dipenuhi dalam menjalani kehidupan ini. Hal ini terlihat dalam Undang-Undang No.20 Tahun 2003 Tentang Sistem Pendidikan Nasional BAB I pasal 1 menyebutkan bahwa pendidikan merupakan usaha sadar dan terencana suasana belajar dan proses belajar agar peserta didik secara aktif mengembangkan potensi dirinya untuk memiliki kekuatan spritual keagamaan, pengendalian diri, kepribadian, kecerdasan akhlak yang mulia, serta keterampilan yang berguna bagi dirinya masyarakat, berbangsa dan negara.

Hasil belajar adalah segala sesuatu yang menjadi milik siswa sebagai akibat dari kegiatan belajar yang dilakukan. Dengan kata lain yang menjadi milik anak adalah menyangkut tentang hasil evaluasi dan pembelajaran yang dilakukan anak. Hasil belajar (achievement) merupakan realisasi atau pemekaran dari kecakapan-kecakapan potensial atau kapasitas yang dimiliki seseorang. Penguasaan hasil oleh seseorang dapat dilihat dari perilakunya, baik perilaku dalam bentuk penguasaan pengetahuan, keterampilan berpikir maupun keterampilan motorik.Hampir sebagian besar dari kegiatan atau perilaku yang diperlihatkan seseorang merupakan hasil belajar. Hasil belajar anak yang belum memenuhi kriteria menjadi hasil dari kurangnya perhatian orang tua terhadap perkembangan belajar anak, sehingga prestasi anak pun menurun.

Untuk mencapai hasil belajar yang baik, banyak faktor yang mempengaruhinya, baik dari diri siswa maupun dari luar diri siswa seperti orang tua maupun lingkungan tempat anak itu tinggal. Orang tua memiliki kewajiban dan tanggung jawab yang besar dalam mendidik dan mengarahkan anak dalam proses belajar. Selain itu, orang tua harus memberikan ilmu dan pengalaman yang nantinya akan bermanfaat untuk bekal masa depan anak. Proses belajar anak di sekolah membutuhkan dorongan dari orang tua. Tanpa dorongan orang tua anak sulit mengikuti proses belajar dengan baik di sekolah.

Peran orang tua dapat berupa perhatian kepada anak, memberi motivasi Page | 66 kepada anak, pemenuhan fasilitas, dan pemberian penghargaan terhadap hasil belajar anak itu sendiri. Perhatian orang tua ini sangat penting bagi anak dalam kegiatan belajar. Slameto (2010:60) berpendapat bahwa dalam lingkungan keluarga, perhatian orang tua dalam belajar anak sangat berpengaruh terhadap hasil belajar anak tersebut. Perhatian memberikan dampak yang baik bagi anak seperti meningkatkan semangat dan motivasi belajar bagi anak. Perhatian dan bimbingan orang tua di rumah akan mempengaruhi kesiapan belajar siswa, baik belajar di rumah maupun di sekolah.

Perhatian adalah pemusatan tenaga psikis yang tertuju pada suatu objek yang datang dari dalam dan luar individu. Perhatian memiliki pengaruh psikologis yang kuat dalam kegiatan belajar anak. Anak cenderung akan giat dan sungguh-sungguh dalam belajar karena merasa diperhatikan dan dianggap penting oleh orang tuanya. Dengan perhatian yang diberikan orang tua maka anak akan merasa bahwa keberhasilanya dalam belajar tidak hanya untuk dirinya namun diharapkan juga oleh orang tuanya.

Kurangnya perhatian intensif orang tua terhadap kegiatan belajar anak sehingga hasil belajar anak dominan menurun. Dalam hal ini orang tua harus lebih memperhatikan aktivitas anak selama menjalani rutinitasnya sebagai pelajar, agar anak mudah dalam mentransfer ilmu selama menjalani proses belajar yang dilaksanakan disekolah maupun di keluarga atau di rumah, agar anak mencapai hasil belajar yang maksimal. Perhatian orang tua yang kurang maksimal dapat menyebabkan anak menjadi malas untuk belajar, karena anak masih memiliki sifat yang mudah bosan dan malas untuk belajar jika tidak didampingi oleh orang tua . Perhatian orang tua dapat berupa pemberian bimbingan dan nasihat, pengawasan 
terhadap belajar, pemberian motivasi dan penghargaan, serta pemenuhan hasil belajar. Semakin baik perhatian orang tua maka dimungkinkan semakin baik pula hasil belajar yang diperoleh anak. Begitu juga sebaliknya, semakin rendah perhatian orang tua maka dimungkinkan semakin rendah pula hasil belajar yang diperoleh anak.

Motivasi orang tua juga sangat penting untuk mencapai hasil belajar yang maksimal. Motivasi orang tua kepada anak termasuk salah satu tugas yang harus di lakukan oleh orang tua. Hal ini sangat penting bagi seorang anak sehingga ia dapat belajar lebih giat tanpa ada perasaan bosan dan lelah. Orang tua yang memotivasi anak cenderung meningkatkan minat belajar dalam diri anak. Sebab motivasi yang diberikan oleh orang tua kepada anaknya sangat dibutuhkan dalam kegiatan belajar. Orang tua dapat memberikan motivasi atau dorongan kepada anak dalam berbagai bentuk termasuk menyediakan makanan kesukaan anak, mengajak anak rekreasi di akhir pekan, memberikan hadiah kepada anak jika ia ingin belajar sungguh-sungguh. Sehingga hasil belajar anak akan meningkat.

Dukungan orang tua sebagai bentuk perhatian tidak hanya memberi motivasi kepada anak. Orang tua juga harus memenuhi asupan gizi kepada anak. Semangat belajar anak akan berkurang akibat kurangnya asupan gizi. Kesehatan dan gizi memiliki hubungan yang tidak dapat dipisahkan antara satu dengan yang lain. Karena kesehatan dan gizi adalah suatu hal yang mendatangkan kebaikan dengan diberikan suatu zat makanan yang dibutuhkan oleh tubuh. Maka dari itu sangat penting untuk orang tua dalam menjaga gizi yang pada anak yang masih mengalami pertumbuhan. Orang tua harus selektif dalam memilih apa yang dikomsumsi oleh anak. Jika anak sudah mendapat asupan makanan yang cukup maka semangat belajar anak pun meningkat. Hasil belajarnya pun akan meningkat juga.

Pada kenyataanya anak sebenarnya mempunyai kemauan dalam hal belajar, tetapi karena cara belajar yang salah, dan orang tua tidak memberikan pengarahan, akhirnya anak merasa sulit untuk belajar.
Mereka mengalami ketinggalan dalam proses belajar. Hal ini dapat terjadi dalam keluarga yang orang tuanya terlalu sibuk dengan urusan mereka sendiri. Bahkan orang tua tidak mau tahu atas prestasi belajar anaknya. Anak juga akan merasa gelisah apabila dia jarang diperhatikan oleh orang tuanya. Kesulitan yang dimiliki anak dalam proses belajarnya akan menyebabkan anak menjadi kurang berhasil mencapai prestasi belajar. Prestasi belajar adalah hasil dari kegiatan pembelajaran, apabila anak ingin dapat prestasi belajar yang baik maka orang tua harus memberikan semangat dan pengarahan anak tersebut, tidak adanya semangat dan bimbingan dari orang tua, anak tidak akan berhasil seperti apa yang diharapkan oleh orang tua. Orang tua yang sibuk terhadap pekerjaan dan kegiatanya, cenderung kurang memperhatikan proses belajar anak. Anak yang tidak mendapatkan perhatian dari orang tuanya akan bertindak semaunya sendiri dan sulit berkonsentrasi saat belajar, hal itu mengakibatkan prestasi belajar anak menurun.

Di Desa Kuta Pengkih merupakan satu desa yang ada di Kecamatan Marding-ding Kabupaten Karo Provinsi Sumatra Utara. Luas desa tersebut 3,2 $\mathrm{km}^{2}$ terdiri dari 892 Kepala keluarga. Ada sebanyak 290 kepala keluarga yang memiliki anak usia 10-12 tahun, dimana sebanyak 271 kepala keluarga yang memiliki anak usia 10-12 tahun yang sedang melaksanakan pendidikanya di sekolah dasar (SD), sisanya ada 19 kepala keluarga yang memiliki anak usia 10-12 tahun yang sudah putus sekolah. Orang tua yang memiliki anak usia 10-12 tahun yang masih sekolah, kurang memperhatikan mengenai perkembangan belajar anaknya, seperti tidak mengerti jadwal pelajaran anaknya, tidak melengkapi alat belajar anaknya, tidak mau tahu kemajuan belajar anaknya, tidak peduli terhadap kesulitan kesulitan yang dialami anaknya dalam belajar dan tidak berusaha tahu hal menyebabkan anak malas untuk belajar, sehingga hasil belajar anak menurun, bahkan membuat anak menjadi tinggal kelas.

Dukungan orang tua untuk anak perlu dilakukan guna menunjang kesuksesan belajarnya dan nantinya akan menjadi orang 
yang sukses seperti apa yang dicitacitakannya sesuai harapan dari orang tuanya. Fenomena yang terdapat Di Desa Kuta Pengkih, sebagian besar orang tua bermata pencaharian sebagai petani. Mereka berangkat pagi pulang sore. Setelah pulang dari ladang, mereka lelah dan istirahat.

\section{METODE}

Sesuai dengan judul penelitian dan tujuan penelitian yaitu untuk mengetahui hubungan perhatian orang tua dengan hasil belajar anak usia 10-12 tahun Desa Kuta Pengkih Kecamatan Marding-ding, maka data penelitian yang diperoleh berupa angka-angka, maka jenis penelitian ini adalah penelitian kuantitatif dengan rancangan penelitian korelasional. Dilihat dari tujuan yaitu mengetahui hubungan perhatian orang tua dengan hasil belajar anak usia 10-13 tahun, maka sifat penelitian ini adalah untuk mengetahui seberapa besar pengaruh variabel $\mathrm{X}$ terhadap variabel $\mathrm{Y}$. Penelitian ini dilakukan di Desa Kuta Pengkih, Kecamatan Marding-ding, Kabupaten karo, Sumatera Utara.

\section{PEMBAHASAN}

Berdasarkan data penelitian yang didapat dari hasil penyebaran angket tentang perhatian orang tua, maka dinyatakan bahwa perhatian orang tua terhadap hasil belajar anak di Desa Kuta Pengkih Kecamatan Marding-ding berada dalam kategori cukup baik. Berdasarkan analisis data yang dilakukan oleh peneliti diperoleh kesimpulan bahwa perhatian orang tua di Desa Kuta Pengkih Kecamatan Marding-ding terbagi dalam 6 indikator antara lain: (1) membimbing anak dalam belajar, (2) mengawasi proses belajar anak, (3) memotivasi anak dalam belajar, (4) memnuhi kebutuhan belajar anak, (5) menciptakan suasana belajar yang yang tenang dan tentram, dan(6) memperhatikan kesehatan anak. Dari indikator tersebut didapatkan hasil 2,47 yang tergolong dalam kategori cukup baik. Yang dihitung dari ratarata nilai setiap indikator.
Dalam penelitian ini, ada dua hipotesis yang akan diuji yaitu pengujian hipotesis dengan mengunakan teknik korelasi product moment untuk mengetahui ada tidaknya hubungan positif antara perhatian orang tua $(\mathrm{X})$ dengan hasil belajar anak usia 10-12 tahun (Y) dan uji-t untuk mengetahui apakah hubungan tersebut signifikan dan keberartiannya.

Hasil pengujian korelasi dan pengujian keberartianya, ada pada lampiran 11. Berikut ini disajikan ringkasan hasil pengujian hipotesis yang menguji ada tidaknya hubungan positif antara perhatian orang tua $(\mathrm{X})$ dengan hasil belajar anak usia 10-12 tahun (Y) ditunjukkan pada Tabel 4.12.

Tabel 1. Ringkasan pengujian Korelasi Variabel X dan Variabel Y

\begin{tabular}{|l|l|}
\hline \multicolumn{2}{|l|}{ Koefisien Korelasi } \\
\hline Rxy & Rtabel $(\alpha=0,05)$ \\
\hline 0,548 & 0,308 \\
\hline
\end{tabular}

Berdasarkan perhitungan diatas, diperoleh $\mathrm{r}_{\mathrm{xy}}=0,548$ pada taraf signifikan $\alpha=$ 0,05 dan $\mathrm{n}=5$, Dari daftar tabel harga kritik untuk $r$ product moment diperoleh $\mathrm{r}_{\text {tabel }}=$ o,308, Dengan membandingan kedua nilai tersebut,diperoleh $r_{\text {hitung }}>r_{\text {tabel }}$ yaitu o,548 > o,308, sehingga dapat disimpulkan bahwa terdapat hubungan antara perhatian orang tua dengan hasil belajar anak usia $10-12$ tahun.

Keluarga atau orang tua adalah orang yang pertama kali menjadi pendidik bagi anak, sehingga dapat dikatakan bahwa keluarga merupakan pendidik yang utama bagi seorang anak. Pendidikan yang diterima anak dirumah tentu sangat mempengaruhi cara belajar anak dan hasil belajar anak disekolah, selain itu pendidikan bukan hanya sekedar ilmu yang diterima anak dari orang tua melainkan perhatian juga sangat diperlukan oleh anak dari orang tua melainkan perhatian juga sangat diperlukan oleh anak untuk menentukan bagaimana anak tersebut disekolah dan juga dapat mempengaruhi hasil belajar dari seorang anak. Jadi dapat disimpulkan bahwa orang 
tua sangat lah berperan dalam kemajuan pendidikan anak. Khususnya dalam hal belajar yang dilakukan oleh anak, baik di lingkungan sekolah ataupun di lingkungan rumah, bagaimana perhatian yang di berikan orang tua sangat mempengaruhi bagaimana karakter anak terutama dalam belajar yang mempengaruhi hasil belajarnya.

\section{Deskripsi Hasil Analisi Perhatian Orang Tua}

Perhatian orang tua adalah pemusatan atau konsentrasi orang tua terhadap anaknya yang di tunjukan dalam berbagai hal yang dilakukan, untuk pemenuhan kebutuhan anak baik berupa jasmani maupun rohani. Hal ini dilakukan untuk kemajuan anak, dalam kehidupan sehari hari mapun dalam proses belajarnya.

Berdasarkan analisis data yang dilakukan oleh peneliti diperoleh kesimpulan bahwa perhatian orang tua di Desa Kuta Pengkih Kecamatan Marding-ding terbagi dalam 6 indikator antara lain: (1) membimbing anak dalam belajar, (2) mengawasi proses belajar anak, (3) memotivasi anak dalam belajar, (4) memnuhi kebutuhan belajar anak, (5) menciptakan suasana belajar yang yang tenang dan tentram, dan(6) memperhatikan kesehatan anak. Dari indikator tersebut didapatkan hasil 2,47 yang tergolong dalam kategori cukup baik. Yang dihitung dari ratarata nilai setiap indikator.

Dengan kata lain perhatian orang tua cukup baik terhadap anak anak untuk meningkatkan hasil belajar anak usia 10-12 tahun di Desa Kuta Pengkih Kecamatan Marding-ding.

\section{Deskripsi Hasil Analisis Hasil Belajar Anak}

\footnotetext{
Hasil belajar anak merupakan suatu ukuran untuk mengetahu tingkat pemahaman seseorang dalam suatu hal. Hal ini sesuai dengan pernyataan Purwanto (2017:46), yang menyatakan hasil belajar merupakan sebagai tingkat penguasaan yang di capai oleh siswa dalam proses belajar mengajar.
}

Perhitungan hasil belajar yang dilakukan oleh peneliti di Desa Kuta Pengkih Kecamatan Marding-ding. Dilihat dari nilai raport anak usia 10-12 tahun pada semester ganjil, sehingga dapat disimpulkan. Terdapat $3 \%$ nilai siswa pada kategori sangat tinggi dan $49 \%$ pada kategori tinggi, dan $41 \%$ pada kategori cukupt tinggi dan $2 \%$ pada kategori rendah. Dengan kata lain jika perhatian orang tua meningkat pada anak maka meningkat pula lah hasil belajar anak tersebut.

\section{Hubungan Antara Perhatian Orang Tua Dengan Hasil Belajar Anak}

Berdasarkan korelasi dari hubungan variabel $X$ (Perhatian Orang Tua) dan variabel Y (hasil belajar anak usia 10-12 tahun) dengan koefisien korelasi yaitu rxy $>$ $\mathrm{r}_{\text {tabel }} \quad(0,387>0,308) \quad$ dan $\quad t_{\text {hitung }}>t_{\text {tabel }}$ $(4,08>2,02)$, sehingga dapat disimpulkan bahwa terdapat hubungan yang signifikan antara perhatian orang tua dengan hasil belajar anak usia 10-12 tahun. Hal ini dapat diartikan bahwa terdapat hubungan yang signifikan antara perhatian orang tua dapat memberikan dampak positif terhadap hasil belajar anak usia 10-12 tahun. Semakin baik perhatian yang diterapkan oleh orang tua maka akan semakin baik pula hasil beajar anak usia 10-12 tahun. Hubungan positif tersebut berarti, semakin tinggi perhatian yang diberikan orang tua maka akan semakin tinggi hasil belajar yang dicapai anak.

\section{SIMPULAN}

Orang tua sebagai orang yang pertama kali menjadi pendidik bagi anak, sehingga orang tua haruslah memberikan pendidikan yang tepat untuk anaknya, bukan hanya materi yang diberikan kepada an ak nya melainkan perhatian juga sangat diperlukan untuk anak, jika perhatian yang diberikan oleh orang tua itu cukup untuk anaknya maka akan memprngaruhi hasil belajar yang diterima anak. Karena terdapat hubungan yang positif dan signifikan anatara perhatian orang tua dan hasil belajar anak. 


\section{Journal of Millennial Community, 2 (2), September 2020}

Sani Susanti, Feby Narco Kacaribu

\section{DAFTAR PUSTAKA}

Ahmadi, Abu. 2009.Psikologi Belajar. Jakarta: Rineka Cipta

Annurahman. 2012. Belajar dan Pembelajaran. Bandung: Alfabeta

Arikunto, Suhrsimin.2013. Prosedur Penelitian suatu pendekatan praktek. Jakarta: Rineka Cipta

Muhubbin. Syah.2011. Psikologi Pendidikan. Bandung: Rosdakarya.

Hamalik, Oemar. 2011. Proses Belajar Mengajar. Jakarta: Bumi Aksara.

Purwanto. 2017. Evaluasi Hasil Belajar. Yogyakarta: Pustaka Pelajar

Slameto.2010. Belajar dan Faktor-faktor yang Mempengaruhinya. Jakarta : Rineka Cipta

Sudjana.Nana. 2010. Penilaian Hasil Proses Belajar Mengajar. Bandung: Rosdakarya

Sugiyono. 2009. Metode Penelitian Pendidikan. Bandung: Alfabeta
Sugiyono. 2010. Statistika Untuk Penelitian. Bandung: Alfabeta

Suharsimin, Arikunto. 2014. Prosedur Penelitian. Jakarta: Asdi Mahasatya Page | 70

Suryabrata, Sumadi. 2013. Psikologi Pendidikan. Jakarta: PT Raja Grafindo Persada

Syarbini. Amirulloh.2014. Model Pendidikan Karakter Dalam Keluarga. Jakarta.Kompas Gramedi

Febriany, Rani dan Yusri. 2013. Hubungan Perhatian Orang tua dengan Motivasi Belajar Siswa dalam mengerjakan Tugas-Tugas Sekolah. Volume 2 nomor 1,(online). Dari http://ejournal.upn.ac.id/index.php/ko nselor . Diunduh pada tanggal 4 April 2016

\section{PROFIL SINGKAT}

Penulis Sani Susanti dan Feby Narco Kacaribu, merupakan Civitas Akademika Pendidikan Masyarakat Universitas Negeri Medan 